\begin{tabular}{|c|c|c|}
\hline $\begin{array}{l}\text { Editorial \& Publishing Offices: } \\
\text { Macmillan \& Co., LTD. } \\
\text { ST. MARTIN's STREET } \\
\text { LONDON, W.C.2 }\end{array}$ & & $\begin{array}{l}\text { Telegraphic Address : } \\
\text { Phusis, LesQUARE, LoNDON } \\
\text { Telephone Number: } \\
\text { WhITEHALL } 88_{3} \text { I }\end{array}$ \\
\hline No. 3462 & SATURDAY, MARCH 7, 1936 & Vol. 137 \\
\hline
\end{tabular}

\title{
Science and Industrial Reconstruction
}

\section{The North-East Coast}

$\mathrm{T}$ HE report on the industrial position of the 'North-East Coast', prepared in 1931 for the Board of Trade by Armstrong College, Newcastleupon-Tyne, has now been supplemented by a new survey conducted by the staff of the Economics Department of Armstrong College under the direction of Mr. E. D. McCallum*. The report on this survey, which covers the years of the depression, has been published, opportunely enough, at a time when the question of remedial measures in the distressed areas is being widely discussed, and when the necessity for research into the suitability of various areas for different manufactures has been emphatically urged by such authorities as Sir Harry McGowan.

In 1931 it was estimated that the volume of labour surplus to the requirements of local industries even in a year of good trade would be 64,000 males. It now appears that this estimate was too low, chiefly because improved methods of production allow of a greater output for an equivalent amount of labour. The report faces the problems which such more or less permanent unemployment and depression create for the community, and points out that it is now generally recognised that the depressed areas cannot themselves solve their problem, and that positive action on the part of the central Government is necessary.

The present investigation indicates that unemployment on the north-east coast of England has been twice as heavy in the years of depression as it was in the pre-depression years, and has con-

* The Industrial Position of the North-East Coast of England. By the Staff of the Economics Department of Armstrong College Newcastle-upon-Tyne. Pp. vii +54 , (London: P. S. King, Ltd.) $28.6 d$. net. tinued to be about twice as severe as in the rest of the country outside the depressed areas. Further, it has continued to be concentrated mainly on male workers. A second feature has been the maintenance and often considerable increase of employment in the lighter industries and services. There has also been a remarkable shift in the distribution of labour from the basic, and in the main, exporting industries, to the lighter industries and services mainly concerned with house consumption.

Finally, the survey shows that the economic depression which began towards the end of 1929 reached its depth in the north-east in 1932. Although there has been some recovery from the worst of the depression, the volume of unemployment, amounting to about 200,000 persons, or 29 per cent of the industrial population of the area, is still twice as great as in 1929. Economic recovery in the area has thus been less marked than in Great Britain as a whole, and much less marked than in the non-depressed areas of the country.

The main problem of the north-east coast of England is the continued depression in the heavy industries, and the survey holds out no hope of the volume of employment in these industries regaining the level of the years before the Great War. The capacity of the heavy industries of the area appears to be in excess of normal post-War requirements. Prospects of it reaching the level of the years preceding the depression are brighter, but are somewhat clouded by restrictions on international trade which have been imposed in many countries through the intensification of economic 
nationalism during the depression. So long as these restrictive measures are followed, there can be little hope of widespread economic recovery in the export industries of the world and therefore in the heavy industries of the north-east coast. The report in this respect gives a timely warning against undue optimism as a result of the partial improvement in the economic position of the country as a whole. Under such conditions recovery is likely to be superficial rather than real, and the danger of further collapse not very remote.

The growth of the lighter industries, however, provides a basis for optimism on the north-east coast, as elsewhere in the country. These industries now employ about half the workpeople of the area, but although they show signs of further growth, in view of their own surplus of labour it would be rash to assume that in the next few years they will be able to absorb the unemployed workers of the heavy industries. Moreover, the fact that they are engaged primarily on the supply of local needs sets limits to their expansion.

Hopes of the establishment of new industries in the area have hitherto been disappointed. The Surveys of Industrial Development published by the Board of Trade show that the north-east coast has failed to attract relatively as many of the new factories as other parts of the country. A memorandum on science and industry submitted last year (1935) to the District Commissioner for Depressed Areas at Newcastle-upon-Tyne laid a good deal of the responsibility for this position upon the absence of foresight and neglect of science by the industrial leadership of the area (see Nature, Aug. 31, 1935). In the survey of the area conducted by Armstrong College in 1935, evidence was cited of failure to grasp the opportunities afforded by new developments which have since reached commercial production outside the area.

It would, nevertheless, be unjust to lay all the responsibility for the present position upon the industrial leaders of the area. With full knowledge of these facts, the present report concludes that without special aid the north-east coast is unable to attract even its proportionate share of the new factories which are being established in the country, and that in the absence of vigorous action on the part of the central Government, large-scale unemployment on the north-east coast is likely to persist.

The lines of Government action have been indicated in a series of recent reports, but the
Tyneside Industrial Development Board has recently directed the attention of the president of the Board of Trade to the way in which the establishment of a new light industry on Tyneside that would have provided work for more than two hundred persons has been prevented by the importation of the glass linings required from Germany at a quotation which undercut the Tyneside quotation by some $£ 3,000$. Had the linings been obtained locally, the manufacture of the vacuum flasks for which they were required would have been established in Tyneside.

This lost opportunity is worthy of note in connexion with the proposals recently advanced by Sir Harry McGowan in commenting at the annual dinner of the British Electrical and Allied Manufacturers Research Association on the failure of virtually all efforts to develop new industries in the distressed areas. Sir Harry suggested that the resources and personnel of the existing develop. ment councils are inadequate and that the grants at the disposal of the Commissioner for the Special Areas in England and Wales should be largely increased. Various ways of finding the money might be considered, but Government contributions towards capital expenditure on plant, machinery and other fixed assets of new industries established in the distressed areas deserve careful attention. We should not be afraid of applying novel expedients to such desperate situations.

The question of personnel is, however, equally important, and without the knowledge and experience of an adequate personnel there can be no assurance of the wise expenditure of public or private grants, or sound decision as to the wisdom of subsidies or other measures in such cases as that recently noted by the Tyneside Industrial Develop. ment Board. Effective action depends primarily upon accurate knowledge, and the requisite know. ledge of the suitability of the special areas for different manufactures and for the development of their potentialities may well require, as Sir Harry McGowan suggested, research extending over several years.

For this research the right type of personnel is required, and not all of this is likely to be found in the area itself, in spite of the greater use that might well be made of the alumni of Armstrong College. The seconding to each area from the Civil Service of one or two workers experienced in the knowledge of proposals likely to prove accept. able to the Government, or skilled in the knowledge of difficulties to be avoided, might well prove an 
invaluable form of Government assistance. Equally the leadership in such survey work might be drawn from industry itself, by industrial firms and associations lending qualified men to explore possibilities of manufacture in the distressed areas.

The sombre picture of the industrial area known as the 'North-East Coast' disclosed by this report is thus not without some rays of hope. While no early solution of the unemployment problem is in sight without effective State intervention, it is clear that with leadership of the right type and effective mobilisation of the natural resources to the task, much can be done. Scientific workers have their own part to play in the necessary exploratory and development work, and they should require no other stimulus than their own sense of citizenship. The heavy burden which lies upon these distressed areas is due only partly to purely economic factors. It is due also to the lopsided development and application of advances in mechanical and physical science, and indirect though his responsibility may be, the scientific worker must take his share in the work of reconstructing the community and enabling it to reap more fully and equably the advantages with which these sciences could endow it.

\section{Babylonian}

\section{Mathematische Keilschrift-Texte}

Herausgegeben und bearbeitet von 0 . Neugebauer. (Quellen und Studien zur Geschichte der Mathematik, Astronomie und Physik, Abteilung A : Quellen, Band 3.) Teil 1 : Texte. Pp. xii +516 . Teil 2 : Register, Glossar, Nachtrage, Tafeln. Pp. iii $+64+69$ plates. (Berlin : Julius Springer, 1935.) 128 gold marks.

IN the past six years our knowledge of the $I_{\text {ancient Babylonian mathematics has been }}$ vastly increased, thanks mainly to the labours of Dr. Neugebauer. The impulse to his researches seems to have come from his attention having been directed to the fact that certain Sumerian and Babylonian texts from the National and University Library of Strassburg, published by C. Frank in 1928, contained six passages of mathematical content. These formed the subject of an article "Zur Geschichte der babylonischen Mathematik" in Part 1 (1929) of Division B (Studien) of the first volume of the series of "Quellen und Studien zur Geschichte der Mathematik, Astronomie und Physik", of which the two volumes before us make up volume 3. Further articles followed, and in 1934 the author's results took definite shape in an admirable volume on "Vorgriechische Mathematik", a notice of which appeared in NATURE of February 23, 1935, p. 283. The greater part of it deals with Babylonian, and the rest mainly with Egyptian, mathematics. The preface to it announced the author's intention to publish separately a collection of all the original texts known and accessible to him (most of them so far unpublished) with the view of giving chapter and verse for the conclusions arrived at. The present large volumes are the result.

\section{Mathematics}

Most of the texts belong to the period, say, from 2000 B.c. until 1800 B.c., and only a few to the Hellenistic period. The first chapter (of 92 pages) deals exhaustively with texts of tables (tables of reciprocals, multiplication tables, tables of squares and cubes, square roots and cube roots, and more general tables, including one of $n$th powers of numbers where $n$ ranges from 2 to 10 ); lengthy extracts from all the classes of tables are given. The remaining chapters give the original cuneiform texts from the Louvre and the British Museum, from Berlin and Strassburg, and from the Yale Babylonian Collection. Each text is first given in a transliteration; this is followed by a German translation, and then by a commentary dealing with all questions of language and content.

The second volume contains elaborate indexes and a glossary, a classification of the texts, references to the whole of the relevant literature, 29 pages dealing in full with texts left over from Part 1 , and 61 fine plates at the end, 34 of which are photographs of the original tablets, while the rest are "Autographien", that is, texts copied in the cuneiform script. The labour involved must have been stupendous, and we can only express our unstinted admiration of the imposing result.

All points of difficulty in the original text, where it is mutilated or defaced, and where there are errors or doubts as to the proper interpretation, are exhaustively discussed ; as to these, experts on cuneiform texts will no doubt have much to say ; here we are concerned only with the mathematical content, which is sufficiently remarkable. The strong point of Babylonian mathematics was arithmetic and algebra rather than geometry, though in geometry they did the usual mensuration of triangles, rectangles, trapezia and parallelepipedal 